\title{
Interspecific competition among fouling organisms in Tomioka Bay, Japan
}

\author{
Kanavillil Nandakumar, Masao Tanaka, Taiji Kikuchi \\ Amakusa Marine Biological Laboratory, Tomioka, Kumamoto-ken 863-25, Japan
}

\begin{abstract}
Time series observations of interspecific competition among fouling organisms on experimental panels were carried out in Tomioka Bay, Japan, using a photosampling technique for $122 \mathrm{~d}$ Altogether 17 species of fouling organisms belonging to various taxonomic groups such as Ascidia, Bryozoa, sponges, Crustacea, Polychaeta and algae were observed. The results of 990 interspecific interactions among the 13 dominant species are presented in the form of a matrix, with significance of the interactions tested using the Chi-square contingency test. The hierarchical order followed the sequence ascidians $>$ sponges $>$ bryozoans $>$ brown algae $>$ barnacles $>$ polychaetes $>$ green algae The main type of interaction observed during the study was overgrowth of one species by another $(71.58 \%)$, while standoffs accounted for the rest. The competitive dominance followed a hierarchical order with numerous back-loops. According to the Chi-square results, the colonial ascidian Diplosoma mitsukurii was ranked as the most dominant species. The correlation between the area coverage of a species and the number of its interactions was found to be highly significant. The merits of time series observations in a competition study of sessile invertebrates compared with static methodology are emphasized.
\end{abstract}

\section{INTRODUCTION}

For sessile suspension-feeding organisms, space is a primary limiting resource (Connell 1961, Knight Jones \& Moyse 1961, Dayton 1971, Stebbing 1973a, Paine 1974, Jackson \& Buss 1975, Jackson 1977, Osman 1977, Russ 1982, Sebens 1986, Lopez Gappa 1989). This limitation subsequently leads to competition for space among the settled organisms. Competition can be of 2 types with respect to the mechanisms involved: exploitation and interference (Park 1954). Various ways of interference can be seen among organisms competing for space, such as crushing or undercutting (Connell 1961, Paine 1971), overshadowing (Lang 1971), applying poison (Goodbody 1961, Bryan 1973, Al-Ogily \& Knight Jones 1977), bulldozing or smothering (Connell 1970, Harger 1972, Osman 1978), and food depletion by one of the competitors (Buss 1979, Best \& Thorpe 1986). However, the most commonly found interference phenomenon is the simple overgrowth of other organisms (Dayton 1971, Stebbing 1973a, b, Sutherland \& Karlson 1977, Russ 1980, 1982, Quinn
1982). Therefore, the degree of competence of a species in space competition can be monitored by its capacity to overgrow neighbors (Stebbing 1973a, Jackson 1979, O'Connor et al. 1980, Russ 1980, Sebens 1986). To date, space competition has been studied on various types of substrata including settling plates (Schoener 1974, Sutherland 1975, 1978, Russ 1982, Lopez Gappa 1989, Myers 1990), coral undersurfaces (Lang 1974, Buss \& Jackson 1979, Benayahu \& Loya 1981, Dai 1990), intertidal and subtidal rocky surfaces (Gordon 1972, Quinn 1982, Sebens 1986), fossils (Liddell \& Brett 1982), and algae (Stebbing 1973a, Sebens 1985, Steneck et al. 1991).

The competitive ability of an organism is influenced by various factors such as size, shape, age and growth rate (Sebens 1982, 1985, 1986). From the frequency of success or competitive ability of each organism in a community, the organisms can be ranked as more or less successful competitors in that community. Such results may produce either a simple hierarchy (Paine 1966, 1974, Dayton 1971, Porter 1972. Connell 1976, Osman 1977) or a complex network (Buss 1976, 1980, Jackson 1979). 
The present study was conducted with the following aims: (1) To measure the competitive ability of the fouling organisms developed on settling panels. (2) To find out whether the competitive ranking system (of success as a competitor) takes the form of a network or a simple hierarchy. (3) To elucidate the relationship between the species area coverage and the number of interactions involved.

For this purpose a time series analysis of a fouling assemblage developed on artificial panels was carried out.

\section{MATERIALS AND METHODS}

The study area was located in Tomioka Bay $\left(32^{\circ} 33^{\prime} \mathrm{N}, 130^{\circ} 02^{\prime} \mathrm{E}\right)$, at the northern end of Amakusa Shimoshima Island, south Japan. A floating pier $(20 \times 8 \times 1.5 \mathrm{~m})$ is moored about $10 \mathrm{~m}$ away from the shore of a secondary cove. Usually, the depth at the pier varies from 2.5 to $5.5 \mathrm{~m}$ at low and high tide respectively and is well protected from heavy swells and waves. Four PVC panels with surfaces roughened with sandpaper were used as artificial substrdies. Duplicate panels $(25 \times 25 \times 0.3 \mathrm{~cm})$ were suspended vertically with one surface (Surface A) facing the light at $1 \mathrm{~m}$ and at $2 \mathrm{~m}$ depth from the water surface. The study period extended from 20 September 1991 to 22 January 1992. During this period the seawater temperature varied from 13.2 to $25.4^{\circ} \mathrm{C}$ (measured almost daily) and the transparency was fairly high (measured at $5 \mathrm{~d}$ intervals), mostly reaching to the bottom at midday

Photosampling. A Nikon FE 2 camera with a $55 \mathrm{~mm}$ micro lens was used for photographing the panels at time intervals of approximately $15 \mathrm{~d}$. Many earlier workers used the photosampling method for studying time series community interactions and fluctuations (Osman \& Haugsness 1981, Sebens 1986, Stocker 1991. Mori 1993). Fuji ASA 400 colour film was used throughout this study. A fixed area of $10 \times 10 \mathrm{~cm}$ at the centre of each panel surface was photographed at the study site after retrieval 9 times during the 4 mo study period. Altogether 72 photographs were taken (2 surfaces $\times 2$ panels $\times 2$ depths $\times 9$ dates); of these 70 were analyzed. This time interval and the area of observation were fixed after running preliminary observations for a period of $4 \mathrm{mo}$.

A metallic quadrat frame essentially the same size as that of the panel was made and subdivided into sixteen $5 \times 5 \mathrm{~cm}$ small quadrats (leaving $2.5 \mathrm{~cm}$ around the edge). This frame was laid exactly over the panel before taking the photograph. By this method we could fix the $10 \times 10 \mathrm{~cm}$ area to the centre of the panels (four $5 \times 5 \mathrm{~cm}$ quadrats) for each observation $( \pm 0.5 \mathrm{~cm})$. This method also eliminated the edge effect completely and the remaining area of the panels supplied ample individuals for identification. The distance between the camera and the panels was kept constant by using a metallic tripod stand of fixed height $(30 \mathrm{~cm})$.

Analysis of photographs. All photographs collected were traced onto transparent sheets with the help of a magnifying glass. All individuals were identified and given separate labels. Species in contact were coded separately. Each tracing was laid over the previous one for that panel surface on a back-lit drafting table. All recognizable changes on the border line of $>1 \mathrm{~mm}$ (real scale) were drawn and the area gained or lost was calculated (data not included in this paper). In contrast to many earlier workers who defined overgrowth as the upward elevation of the growing edge of one colony over the other to the extent that it covers the opening of the other's zooid (in the case of Bryozoa), here overgrowth between colonial organisms is defined as the growth of one species over the other to the extent of more than $5 \%$ of the size of the overgrown species, and the overgrowing species is then considered as the winner. Where solitary organisms were involved, the upward elevation of colonial organisms over solitary ones or the settlement and growth of solitary oganisms over colonial ones was considered as a win for the corresponding species. Otherwise the contact was considered as standoff or coexistence. The $5 \%$ area was fixed arbitrarily assuming that, once a species could overgrow the other this much, then it can overgrow the other completely with time. Each standoff interaction was monitored consecutively 3 times (about 45 d); those which could not be observed for this duration were not included in the results as standoffs. Those interactions which could not proceed to the level of $5 \%$ area of the overgrown species, and those where growth stopped at the edge of contact, were recorded as standoffs. Harris (1978) and Russ (1982) found that simple elevation of the edge of a species over the other could ultimately result in a standoff between the 2 species or a reversal of overgrowth by which the species with an elevated margin would in due course be overgrown by the subordinate species. Thus, in the present study 3 conditions of overgrowth were considered: win, loss and standoff or coexistence.

Because this study depended entirely on photosampling, the 3-dimensional growth of the organisms could not be considered. The contacts of erect organisms such as Bugula neritina, B. californica and the algae Enteromorphasp. and Colpomenia sinuosa were considered only when the attachment base could be clearly seen to be in contact with the other organisms (Sebens 1986). The shade effect of the erect organisms was considered to be negligible and hence omitted from the analysis. 
The rate of areal increase of a species during the present study was calculated by dividing the area covered by that species by age (no. of days after appearance). This is subject to an error of about an observation interval. Since a depthwise difference was not observed in the data of species composition, sequence of colonization and percentage area cover, all 4 panels were treated together for further analysis.

Analysis of data. In order to assess the competitive dominance among the interacting species, Chi-square contingency tests $\left(x^{2}\right)$ were carried out (Sokal \& Rohlf 1987). Here, the null hypothesis was that there is equal probability for win and loss (measured as competitive ability) between each pair of interacting species. Rejection of the hypothesis with a significance level of $p<0.05$ was considered as significant and the species which won the majority of the reactions was considered as the competitive dominant over the other. Only species pairs with 4 or more interactions were considered for the analysis. Where standoffs were recorded, these were converted to the average population winning rate by giving separate points ( 2 points for the winner, 0 for the loser and 1 point for each species in cases of standoff) and Chi-square was carried out on the sums of these points (Russ 1982). The results are given in the form of a matrix. From these results the competitive hierarchy is constructed. Throughout this study, morphological features such as individual colony area, thickness, and age and the many intraspecific encounters that occurred were not taken into account while interpreting the results of the competition.

From the above results, 8 dominant species were selected for further analysis. In order to investigate the relationship between the percentage area cover and the number of interactions involved, Kendall's coefficient of rank correlation $(\tau)$ was calculated for each species (Jackson 1979, Karande \& Swami 1988).

\section{RESULTS}

\section{Species composition, sequence of appearance and area coverage}

Table 1 lists the fouling organisms found on the 4 experimental panels during the 4 mo of study. Altogether there were 17 species; among them, the polychaetes of the species Hydroides elegans and Serpula kaempferi were very difficult to distinguish in the photographs due to the morphological similarity of their calcareous tubes. Hence, in further analyses these 2 species were treated together as 'serpulid worms'. Also, the barnacle species Balanus amphitrite and B. trigonus and the solitary ascidian Styela plicata were observed on very rare occasions (together $<2 \%$ of the
Table 1 List of fouling organisms that appeared on the experimental panels

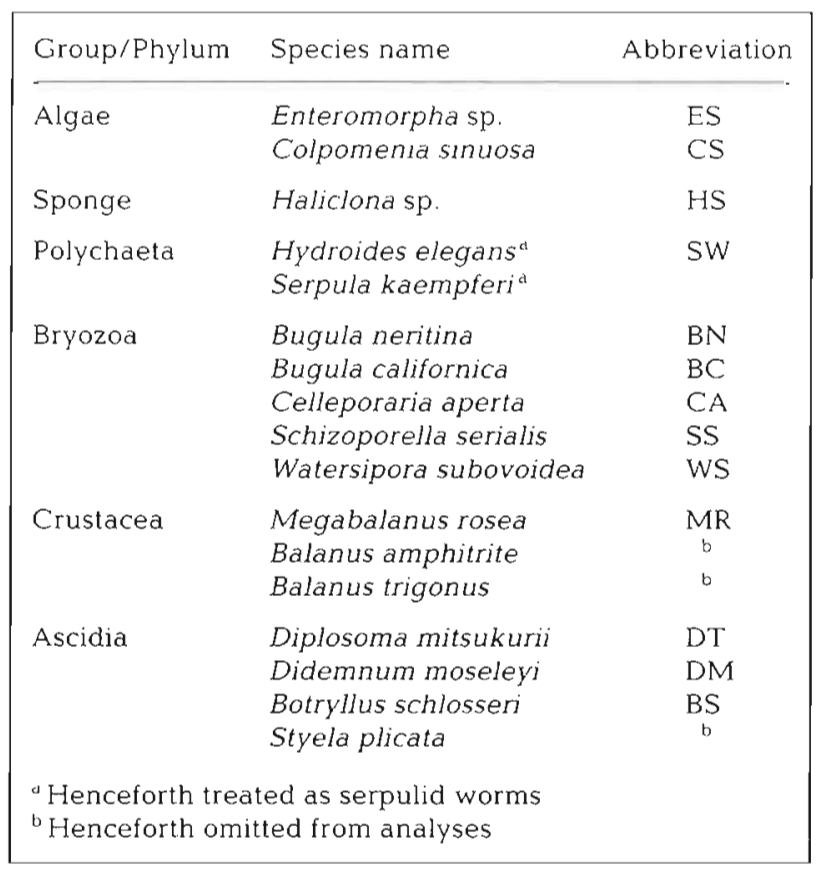

total fouling coverage) and hence were not included in further analyses. The percentage cover of the remaining 13 species with time is given in Fig. 1. At the end of observations (122 d), ascidians and bryozoans occupied almost equal areas, i.e. 30.17 and $31.38 \%$ of the total panel surface respectively. Among them, the colonial ascidian Diplosoma mitsukurü occupied the largest area $(24.85 \%)$ and the erect bryozoan Bugula californica occupied the smallest area $(0.06 \%)$ (Fig. 1 ).

The time and sequence of appearance of each species is shown in Fig. 2. The earlier colonizers such as serpulid worms, the encrusting bryozoan Schizoporella serialis and the barnacle Megabalanus rosea showed a rapid increase at the beginning but towards the end of the study decreased in area coverage (Fig. 1). In the case of later colonizers, such as the sponge Haliclona sp., brown algae Colpomenia sinuosa, encrusting bryozoans Celleporaria aperta and Watersipora subovoidea, and the colonial tunicates Diplosoma mitsukurii, Botryllus schlosseri and Didemnum moseleyi, the area coverage increased constantly throughout the study. However, an exception to this trend was observed in the case of green algae Enteromorpha sp. (Figs. $1 \& 2$ ).

\section{Results of interactions}

The results of interactions of the 13 fouling species after the Chi-square contingency test is given in Fig. 3. In total there were 990 interspecific interactions 
observed of which $708(71.52 \%)$ were direct overgrowth and the remaining $282(28.48 \%)$ were standoffs.

To determine the competitive hierarchy among the species studied here, the Chi-square contingency test results (as a measure of competence) were plotted (Fig. 4). It is clear that the dominant species observed was Diplosoma mitsukurii and the most recessive one in the order was the erect algae Enteromorpha sp. Also these results show a more or less hierarchical type of relationship among the species studied. As observed by Russ (1982) for fouling assemblages in Australia, the most dominant fouling species, D. mitsukurii, was found to be defeated in a few instances by other species which were ranked low in the order of competitive hierarchy (back-loop), showing a lack of absolute dominancy.

\section{Relationship between percentage area cover and number of inter- actions involved}

As described above, Kendall's coefficient of rank correlation was calcu-
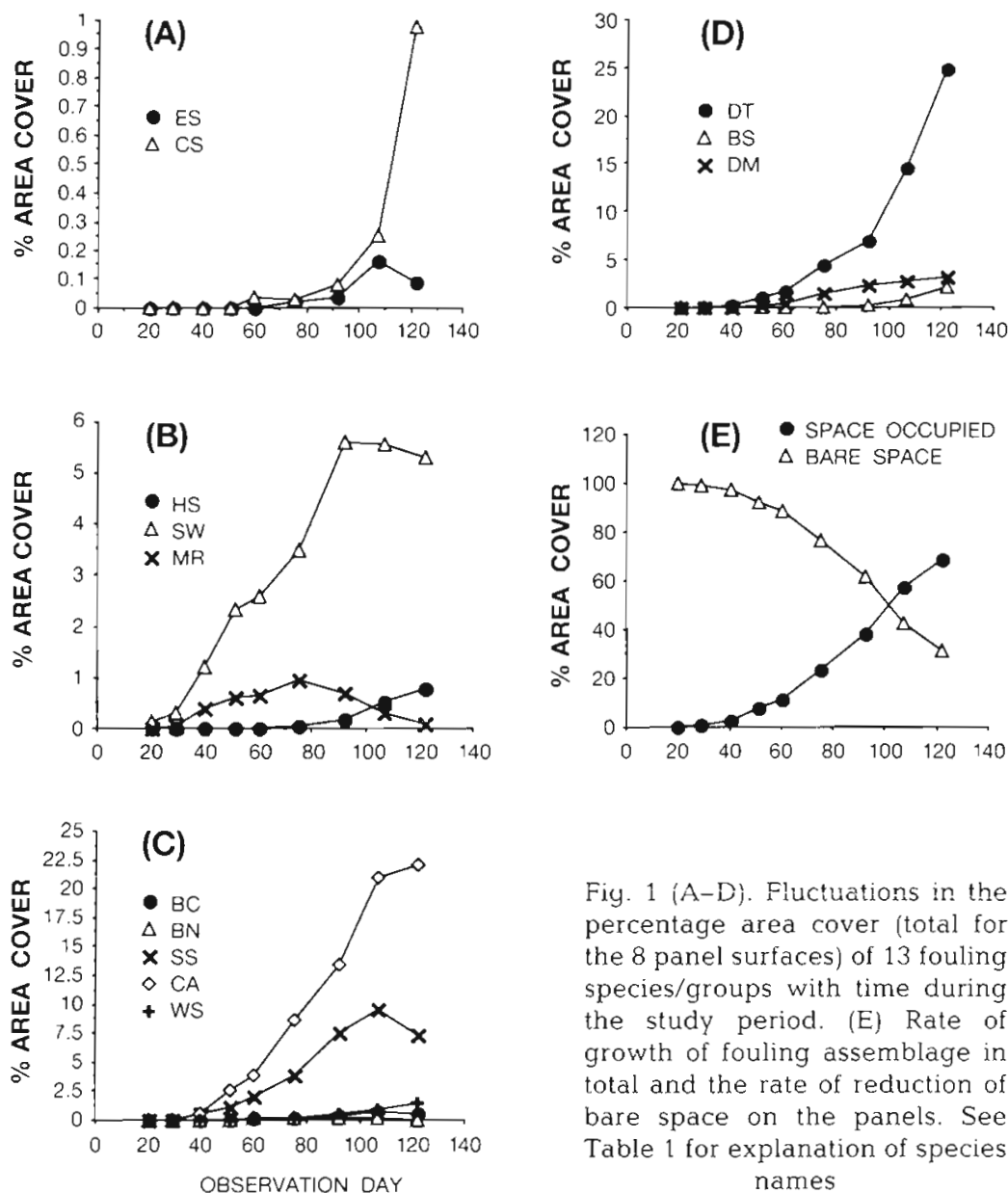

Fiy. 1 (A-D). Fluctuations in the percentage area cover (total for the 8 panel surfaces) of 13 fouling species/groups with time during the study period. (E) Rate of growth of fouling assemblage in total and the rate of reduction of bare space on the panels. See Table 1 for explanation of species names

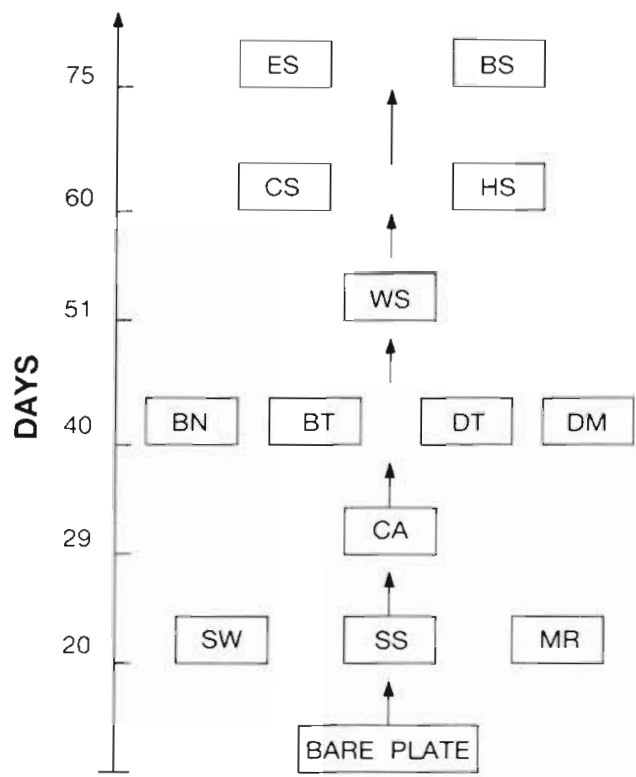

Fig. 2. Sequence of appearance of the fouling organisms with time lated for the 8 competitively dominant species. The coefficient $\tau$ was found to be highly significant $(p<0.05)$ in the majority of the species tested (Table 2 ). The system considered here is believed to be a rapidly growing one (Fig. 1). And, since the majority of the encounters resulted in the overgrowth of one of the species $(71.52 \%)$, this correlation also suggests that the larger the area the fouling organisms occupy the greater the number of overgrowth interactions these species undergo. A similar result was reported by Jackson (1979) and Karande \& Swami (1988), while studying the cheilostome bryozoans.

Table 3 indicates the number of interactions completed with time of observation. This is done to know the importance of time series observations on the study of competition among sessile organisms. After $107 \mathrm{~d}, 253$ of a total of 990 interactions $(>25 \%)$ came to an end and could not be traced during the $122 \mathrm{~d}$ observation. This included the death and removal of smaller colonies of ascidians, sponges, bryozoans, barnacles, polychaetes and algae. 


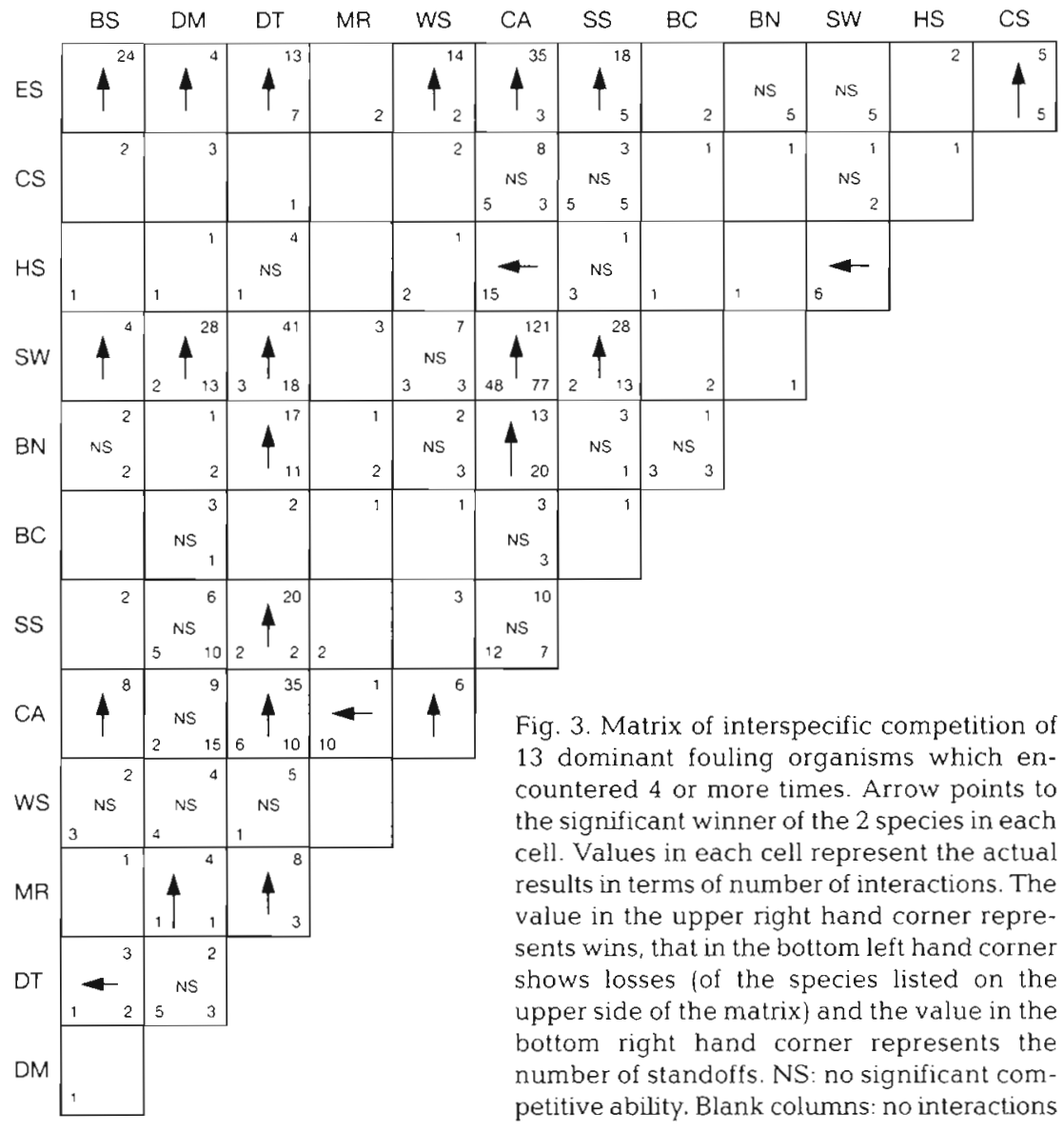

\section{DISCUSSION}

According to Sebens (1986), the ultimate goal in studying interspecific competition is the explanation of community development and persistence of multispecies systems through time. Many earlier workers have found that the time of colonization of a species is highly correlated with its position in the order of hierarchy (Sutherland \& Karlson 1977, Sebens 1986). In the present study also, the initial colonizers were observed to be less competent than the secondary colonizers (Figs. 2 \&4). Many modelling studies were also carried out based on this assumption (e.g. MacArthur \& Levins 1964, Armstrong 1976, Connell \& Slatyer 1977). However, the persistence of initial colonizers is mainly governed by 2 mechanisms: (1) their long-term survival even after overgrowth, as observed by Todd \& Turner (1988); and (2) rapid recruitment (Sebens 1986). In the present study the second type of mechanism was usually observed among the serpulid worms.

The competitive hierarchy of the taxonomic groups in this study followed the pattern: ascidians $>$ sponges $>$ bryozoans $>$ brown algae $>$ barnacles $>$ serpulid worms $>$ green algae. This order seems to be more or less the same as that observed by Russ (1982) in Australia. The colonial ascidians with their soft bodies, varying thickness and rapid growth rate came at the top of the hierarchy. However, as suggested by Buss \& Jackson (1979), where a network type of competitive relationship exists, the time taken for a single species to monopolize the substratum would be greater than that if a hierarchical type system existed. In the present study, a complete monopolization of the substratum by a single species could not be seen. Nevertheless, as time passed the complexity of the assemblage increased (Fig. 2) and most of the area $(>60 \%)$ was occupied by colonial ascidians and encrusting bryozoans. However the single species monopolization time differed widely between substrata with a complex initial settlement and substrata with a less complex
Fig. 4. Hierarchical order as obtained from the Chi-square contingency test analysis. Bold lines with arrows point to the loser 
Table 2. Relationship between percentage cover (upper row) and number of interactions involved (in parentheses) by 8 competitively dominant species with time. The significance of the relationship ( $p$ ) is tested by Kendall's coefficient of rank correlation test. n: no. of samples

\begin{tabular}{|ccccccccccc|}
\hline \multirow{2}{*}{ Species } & \multicolumn{8}{c}{ Observation day after deployment } & \multirow{2}{*}{$\mathrm{n}$} & $\mathrm{p}$ \\
& 40 & 51 & 60 & 75 & 92 & 107 & 122 & & \\
\hline CS & 0 & 0 & 0 & 0 & 0.08 & 0.25 & 0.98 & 3 & 0.1172 \\
& & & & & $(2)$ & $(9)$ & $(27)$ & & \\
HS & 0 & 0 & 0 & 0.06 & 0.16 & 0.05 & 0.78 & 4 & 0.0415 \\
& & & & $(6)$ & $(7)$ & $(22)$ & $(38)$ & & \\
CA & 0.64 & 2.52 & 3.78 & 8.61 & 13.43 & 20.97 & 22.07 & 7 & 0.0016 \\
& $(5)$ & $(18)$ & $(56)$ & $(140)$ & $(215)$ & $(340)$ & $(445)$ & & \\
SS & 0.52 & 1.02 & 2.07 & 3.80 & 7.49 & 9.48 & 7.30 & 7 & 0.0043 \\
& $(1)$ & $(10)$ & $(19)$ & $(48)$ & $(58)$ & $(80)$ & $(74)$ & & \\
WS & 0 & 0 & 0.03 & 0.20 & 0.58 & 0.99 & 1.49 & 5 & 0.0143 \\
& & & $(2)$ & $(5)$ & $(10)$ & $(17)$ & $(24)$ & & \\
DT & 0.23 & 1.13 & 1.59 & 4.35 & 6.98 & 14.48 & 24.85 & 7 & 0.0016 \\
& $(4)$ & $(9)$ & $(15)$ & $(66)$ & $(78)$ & $(168)$ & $(179)$ & & \\
DM & 0 & 0.11 & 0.35 & 1.56 & 2.39 & 2.70 & 3.12 & 6 & 0.0048 \\
& & $(3)$ & $(8)$ & $(48)$ & $(64)$ & $(69)$ & $(90)$ & & \\
BS & 0 & 0 & 0 & 0.07 & 0.15 & 0.92 & 2.20 & 4 & 0.0628 \\
& & & & $(1)$ & $(1)$ & $(7)$ & $(17)$ & & \\
\hline
\end{tabular}

1989) in bryozoans, the size and age of the species play a significant role in determining survivorship during interaction with others.

In the present study, a clear hierarchy could be seen among the fouling organisms (Fig. 4). The 2 major species, the colonial ascidian Diplosoma mitsukurii $(24.85 \%)$ and the encrusting bryozoan Celleporaria aperta $(22.07 \%)$, constituted nearly $50 \%$ of the total panel surface and nearly $70 \%$ of the fouling assemblage. However, of these 2 species, the colonial ascidian was found to be the dominant one. Its colony size and the rate of increase of areal coverage (Fig. 1) played a major role in its success as a dominant competitor, rather than the thickness. The average thickness of the $D$. mitsukurii colony was found to be considerably less than that of the other species of ascidians and bryozoans over which it showed a clear supremacy (pers, obs.). The second dominant species with respect to the area settlement. Panel surfaces with thicker and more complex settlement of initial colonizers delayed settlement and overgrowth by secondary settlers (pers. obs.). Regarding the fluctuations in area coverage, all organisms showed a more or less consistent increase during the first $92 \mathrm{~d}$ of observation, but thereafter, the coverage of most of the primary settlers decreased while that of the secondary settlers rapidly increased. The decrease in the area coverage of the primary settlers was due to the increased overgrowth of the secondary settlers (Fig. 1). However, as shown by Keough (1986,

Table 3. Number of interactions completed on both surfaces of the 4 experimental panels with time. Observation only after $122 \mathrm{~d}$ would have missed these previously completed interactions. Ni none completed

\begin{tabular}{|c|c|c|c|c|c|c|c|}
\hline \multirow[t]{2}{*}{ Panel } & \multirow[t]{2}{*}{ Surface } & \multicolumn{6}{|c|}{ Time in days after deployment } \\
\hline & & 40 & 51 & 60 & 75 & 92 & 107 \\
\hline \multirow[t]{2}{*}{1} & A & 1 & 1 & $N$ & 2 & 4 & 9 \\
\hline & B & $\mathrm{N}$ & 1 & 6 & 18 & 34 & 17 \\
\hline \multirow[t]{2}{*}{2} & A & $\mathrm{N}$ & $\mathrm{N}$ & 2 & $N$ & 6 & 7 \\
\hline & B & $\mathrm{N}$ & N & $N$ & 1 & $N$ & 7 \\
\hline \multirow[t]{2}{*}{3} & A & $N$ & $\mathrm{~N}$ & $N$ & 2 & 2 & 12 \\
\hline & B & $N$ & 4 & 5 & 26 & 42 & 8 \\
\hline \multirow[t]{2}{*}{4} & A & $N$ & $N$ & 1 & $\mathrm{~N}$ & 1 & 3 \\
\hline & B & $\mathrm{N}$ & $N$ & $\mathrm{~N}$ & 2 & 9 & 20 \\
\hline \multicolumn{2}{|l|}{ Total } & 1 & 6 & 14 & 51 & 98 & 83 \\
\hline \multicolumn{6}{|c|}{ Total interactions observed during the study } & 9 & \\
\hline \multicolumn{6}{|c|}{ Total interactions completed by $107 \mathrm{~d}$} & \multicolumn{2}{|c|}{$253(25.56 \%)$} \\
\hline
\end{tabular}

coverage ( $C$. aperta) could be only ranked as 3 rd level in the hierarchical order (Fig. 4). This species, even though it possessed a high rate of areal coverage (as a preliminary occupier of the space) (Fig. 1), lacked the capacity to overgrow the other colonial organisms at the line/point of interspecific contact.

The hierarchy constructed in this study is based on the Chi-square test results. Although the competitive dominancy could be shown statistically, there were many back-loops, as mentioned by Russ (1982) and Quinn (1982) in their studies (Fig. 3). Here, Watersipora subovoidea, Celleporaria aperta, Schizoporella clona sp., the colonial ascidians Diplosoma mitsukurii, Didemnum moseleyi and Botryllus schlosseri all won against each other in at least a few interactions.

The index of intransitivity as suggested by Rubin (1982) was not applied here, since our study showed a very high percentage of standoffs $(28.48 \%)$ in which a majority of the interactions resulted in a simple cessation of growth at the line/point of contact. Since Rubin (1982) derived the index of intransitivity after taking into consideration only win or loss of the species in the interspecific competition, we consider it inadequate to apply in our system with a very high percentage of standoffs. Very high percentages of standoffs were also reported earlier (Russ 1982, Sebens 1985, Schmidt \& Warner 1986).

Jackson (1979), while studying the cheilostome ectoprocts of the Jamaican reef environment, suggested that there is a close relationship between colony size serialis (all encrusting bryozoans), the sponge Hali- 
and the number of interactions that colony encountered. In the present study also, Kendall's coefficient of rank correlation proved to be highly significant in the majority of species tested (Table 2). It is interesting that this significant correlation indicates roughly the nature of the species assemblage (even or patchy) and the state of its development.

As mentioned by Sebens (1986), previous studies of competition for space have mainly concentrated on the overgrowth observations carried out at a particular point of time (Stebbing 1973a, Buss \& Jackson 1979, Jackson 1979, O'Connor et al. 1980, Russ 1980, 1982, Quinn 1982, Rubin 1982 and many others). Unlike Sebens (1986), who did his studies on rocky substrata, this study was carried out on artificial substrata, where the growth rate was high. This in turn necessitated a shorter time interval for the sampling. In spite of this shorter period of observation with shorter sampling intervals, the importance of the time series observations for this competition study of sessile marine invertebrates could be clearly seen (see Fig. 2 for the fluctuations of percentage area cover and the rate of areal increase and Table 3 for the number of interactions involved with time). These results also revealed that the static sampling method would not only have missed the progressive changes in community development (such as the interactions involved and the modifications that occurred due to these interactions), but would also have led to errors in distinguishing the actual results of the overgrowth (Sebens 1986).

Acknowledgements. We thank Prof. Teruaki Nishikawa, Biological Laboratory, Nagoya University, and Prof. Shunsuke Mawatari, Faculty of Science, Hokkaido University, for kindly identifying the ascidian and bryozoan samples, respectively. We gratefully acknowledge the help of $\mathrm{Mr}$ I. Goto in providing the daily temperature data of the seawater and $\mathrm{Mr}$ $T$. Samashima for excellent field assistance. We also thank the 3 anonymous referees for their valuable suggestions on the manuscript. The first author acknowledges the Ministry of Science and Culture, Japan, for the award of a doctoral fellowship. This is Amakusa Mar. Biol. Lab. contribution No. 369.

\section{LITERATURE CITED}

Al-Ogily, S. M., Knight Jones, E. W. (1977). Antifouling role of antibiotics produced by marine algae and bryozoans. Nature 265: 728-729

Armstrong, R. A. (1976). Fugitive species: experiments with fungi and some theoretical considerations. Ecology 57 : 953-963

Benayahu, Y., Loya, Y. (1981). Competition for space among coral-reef sessile organisms at Eilat, Red Sea. Bull. mar. Sci. 31: $514-522$

Best, M. A., Thorpe, J. P. (1986). Feeding-current interactions and competition for food among the bryozoan epiphytes of Fucus serratus. Mar. Biol. 93: 371-375
Bryan, P. G. (1973). Growth rate, toxicity and distribution of the encrusting sponge, Terpios sp. (Hadromerida: Suberitidae) in Guam, Marianas Islands. Micronesica 9: 237-242

Buss, L. W. (1976). Better living through chemistry: the relationship between allelochemical interactions and competitive networks. In: Harrison, F. W., Cowden, R. R. (eds.) Aspects of sponge biology. Academic Press, New York, p. $315-327$

Buss, L. W. (1979). Bryozoan overgrowth interactions - the interdependence of competition for space and food Nature 281: 475-476

Buss, L. W. (1980). Competitive intransitivity and size frequency distributions of interacting populations. Proc. natl Acad. Sci. U.S.A. 77: 5255-5259

Buss, L. W., Jackson, J. B. C. (1979). Competitive networks: nontransitive competitive relationships in cryptic coral reef environments. Am. Nat. 113: 223-234

Connell, J. H. (1961). The influence of interspecific competition and other factors on the distribution of the barnacle Chthamalus stellatus. Ecology 42: 710-723

Connell, J. H. (1970). A predator-prey system in the marine intertidal region. I. Balanus glandula and several predatory species of Thais. Ecol. Monogr. 40: 49-78

Connell, J. H. (1976). Competitive interactions and the species diversity of corals. In: Mackie, G. O. (ed.) Coelenterate ecology and behaviour. Plenum Press, New York, p. 51--58

Connell, J. H., Slatyer, R. O. (1977). Mechanisms of succession in natural communities and their role in community stability and organization. Am. Nat. 111: 1119-1144

Dai, C. F. (1990). Interspecific competition in Taiwanese corals with special reference to interactions between alcyonaceans and scleractinians. Mar. Ecol. Prog. Ser. 60: $291-297$

Dayton, P. K. (1971). Competition, disturbance and community organization: the provision and subsequent utilization of space in a rocky intertidal community. Ecol. Monogr. 41: 351-389

Goodbody, I. (1961). Inhibition of the development of a marine sessile community. Nature 190:282-283

Gordon, D. P. (1972). Biological relationships of an intertidal bryozoan population. J. nat. Hist. 6: 503-514

Harger, J. R. E. (1972). Competitive co-existence: maintenance of interacting associations of the sea mussels Mytilus edulis and Mytilus californianus. Veliger 14: $387-410$

Harris, J. A. (1978). The ecology of marine epifaunal communities on the pilings of Portsea pier. B.Sc. thesis, Dept Zool., Univ. Melbourne

Jackson, J. B. C. (1977). Competition on marine hard substrata: the adaptive significance of solitary and colonial strategies. Am. Nat. 111: 743-767

Jackson, J. B. C. (1979). Overgrowth competition between encrusting cheilostome ectoprocts in a Jamaican cryptic reef environment. J. Anim. Ecol. 48: 805-823

Jackson, J. B. C., Buss, L. W. (1975). Allelopathy and spatial competition among coral reef invertebrates. Proc. natl Acad. Sci. U.S.A. 72: 5160-5163

Karande, A. A., Swami, B. S. (1988). Overgrowth competitions amongst encrusting cheilostomes. Proc. Indian Acad. Sci. (Anim. Sci.) 97: 141-149

Keough, M. J. (1986). The distribution of the bryozoan on seagrass blades: settlement growth and mortality. Ecology 67: 846-857

Keough, M. J. (1989). Variation in growth rate and reproduction of the bryozoan Bugula neritina. Biol. Bull. 177 $277-286$ 
Knight Jones, E. W., Moyse, J. (1961). Intraspecific competition in sedentary marine animals. Symp. Soc exp. Biol. 15: $72-95$

Lang, J. C. (1971). Interspecific aggression by scleractinian corals. I. The rediscovery of Scolymia cubensis (MilneEdwards and Haime). Bull. mar. Sci. 21: $952-959$

Lang, J. C. (1974). Biological zonation at the base of a reef Am. Sci. 62: 272-281

Liddell, W D., Brett, C. E. (1982). Skeletal overgrowths among epizoans from the Silurian (Wenlockian) Waldron Shale. Paleobiology 8: 67-78

Lopez Gappa, J. J. (1989). Overgrowth competition in an assemblage of encrusting bryozoans settled on artificial substrata. Mar. Ecol. Prog. Ser. 51: 121-130

MacArthur, R. H., Levins, R. (1964). Competition, habitat selection and character displacement in a patchy environment. Proc. natl Acad. Sci. U.S.A. 51: $1207-1210$

Mori, K. (1993). Settlement site selection in the intertidal barnacle Chthamalus challengeri Hoek at exposed and sheltered shores in Amakusa, Japan. J. exp. mar. Biol. Ecol. (in press)

Myers, P. E. (1990). Space versus other limiting resources for a colonial tunicate, Botrylloides leachii (Savigny), on fouling plates. J. exp. mar. Biol. Ecol. 141:47-52

O'Connor, R. J., Seed, R., Boaden, P. J. S. (1980). Resource space partitioning by the bryozoa of a Fucus serratus $\mathrm{L}$. community. J. exp. mar. Biol. Ecol. 45: 117-137

Osman, R. W. (1977). The establishment and development of a marine epifaunal community. Ecol. Monogr. 47: 37-63

Osman, R. W. (1978). The influence of seasonality and stability on the species equilibrium. Ecology 59: 383-399

Osman, R. W. Haugsness, J. A. (1981). Mutualism among sessile invertebrates: a mediator of competition and predation. Science 211: 846-848

Paine, R. T (1966). Food web complexity and species diversity. Am. Nat. 100:65-75

Paine, R. T. (1971). A short term experimental investigation of resource partitioning in a New Zealand rocky intertidal habitat. Ecology 52: 1096-1106

Paine, R. T. (1974). Intertidal community structure: experimental studies on the relationship between a dominant competitor and its principal predator. Oecologia 15: 93-120

Park, $T$ (1954). Experimental studies of interspecies competition. II. Temperature, humidity and competition in two species of Tribolium. Physiol. Zool. 27: 177-238

Porter, J W. (1972). Predation by Acanthaster and its effect on coral species diversity. Am. Nat. 106: 487-492

Quinn, J. F. (1982) . Competitive hierarchies in marine benthic communities. Oecologia 54:129-135

Rubin, J. A. (1982). The degree of intransitivity and its measurement in an assemblage of encrusting cheilostome Bryozoa. J. exp. mar. Biol. Ecol. 60:119-128
Russ, G. R. (1980). Effects of predation by fishes, competition and structural complexity of the substratum on the establishment of a marine epifaunal community. J. exp. mar. Biol. Ecol. 42: 55-69

Russ, G. R. (1982). Overgrowth in a marine epifaunal community: competitive hierarchies and competitive networks Oecologia 53: 12-19

Schmidt, G. H., Warner, G. F. (1986). Spatial competition between colonial ascidians: the importance of stand-off. Mar. Ecol. Prog. Ser. 31. 101-104

Schoener, A. (1974). Experimental zoogeography: colonization of marine mini islands. Am. Nat. 108: 715-738

Sebens, K. P. (1982). Competition for space: growth rate, reproductive output and escape in size. Am. Nat. 120: $189-197$

Sebens, K. P. (1985). Community ecology and subtidal rock walls in the Gulf of Maine, USA: small scale process and alternative community states. In: Moore, P. G., Seed, R. (eds.) The ecology of rocky coasts. Hodder \& Stoughton Educational, Sevenoaks, p. 346-371

Sebens, K. P. (1986). Spatial relationships among encrusting marine organisms in the New England subtidal zone. Ecol. Monogr. 56: 73-96

Sokal, R. R., Rohlf, F. J (1987). Introduction to biostatistics, 2nd edn. W. H. Freeman \& Co., New York

Stebbing, A. R. D. (1973a). Competition for space between the epiphytes of Fucus serratus L. J. mar. biol. Ass. U.K. 53: $247-261$

Stebbing, A. R. D. (1973b). Observations on colony overgrowth and spatial competition. In: Larwood, G. P. (ed.) Living and fossil Bryozoa. Academic Press, London, p. $173-183$

Steneck, R. S., Hacker, S. D., Dethier, M. N. (1991). Mechanisms of competitive dominance between crustose coralline algae: an herbivore-mediated competitive reversal. Ecology 72: $938-950$

Stocker, L. J (1991). Effects of size and shape of colony on rates of fission, fusion, growth and mortality in a subtidal invertebrate. J. exp. mar. Biol. Ecol. 149: 161-175

Sutherland, J. P. (1975). Effects of Schizoporella removal on the fouling community at Beaufort, N.C. In: Coull, B. C. (ed.) Ecology of marine benthos. Univ. South Carolina Press, Columbia, p. 155-189

Sutherland, J. P. (1978). Functional roles of Schizoporella and Styela in the fouling community at Beaufort. North Carolina. Ecology 59: 257-264

Sutherland, J. P., Karlson, R. H. (1977). Development and stability of the fouling community at Beaufort, North Carolina. Ecol. Monogr. 47: 425-446

Todd, C. D., Turner, S. J. (1988). Ecology of intertidal and sublittoral cryptic epifaunal assemblages. II. Nonlethal overgrowth of encrusting bryozoans by colonial ascidians J. exp. mar. Biol. Ecol. 115: 113-126

Manuscript first received: June 11, 1992

Revised version accepted: February 3, 1993 